\title{
Behavior and Strength Predictions for CFRP Confined Rubberized Concrete under Axial Compression
}

\author{
Rana Faisal Tufail ${ }^{1,2}$, Xiong Feng ${ }^{1}$, Danish Farooq ${ }^{2}$, Nabil Abdelmelek ${ }^{3 *}$, Éva Lublóy ${ }^{3}$, \\ Ahsen Maqsoom ${ }^{2}$ \\ College of Architecture and Environment, Sichuan University, 610065 Chengdu, China \\ ${ }^{2}$ Civil Engineering Department, COMSATS University Islamabad, Wah Campus, 47040 Wah, Pakistan \\ ${ }^{3}$ Department of Construction Material and Technologies, Faculty of Civil Engineering, Budapest University of Technology and Economics, \\ H 1111 Budapest, Hungary \\ * Corresponding author, e-mail: abdelmelek.nabil@emk.bme.hu
}

Received: 07 July 2019, Accepted: 04 May 2020, Published online: 05 October 2021

\begin{abstract}
This paper presents experimental versus theoretical comparison of carbon fiber reinforced polymer (CFRP) confined rubberized concrete (a new structural material). A total of sixty six rubberized concrete cylinders were tested in axial compression. The specimens were cast using 0 to 50\% rubber replacement. Twenty seven cylinders were then confined with one, two and three layers of CFRP jackets. Axial compression results of the experimental study were compared with the North American and European design guidelines. The results indicate that the addition of rubber content in the concrete leads to premature micro cracking and lateral expansion in concrete. This increased lateral dilation exploited the potential of FRP jackets. The axial compressive strength and strain values for CFRP confined RuC cylinders reached up to unprecedented 600 and 330 percent of unconfined samples. Furthermore, the current international design guidelines developed for conventional concrete confinement failed to predict the compressive strength of rubberized concrete. There is a strong need to re-evaluate the current design codes and their applicability to investigate fiber reinforced confined rubberized concrete. Moreover, the proposed equations in this research can better predict the axial compressive strength of FRP confined RuC.
\end{abstract}

\section{Keywords}

FRP, RuC, rubberized concrete, design guidelines, model, fiber reinforced polymer, compressive strength, strain

\section{Introduction}

Waste tires are usually landfilled and can cause environmental and public health issues. This reason has led towards generating innovating applications for scrap tires containing volcanized rubber and their components in construction industry [1-5]. The benefits of using vulcanized rubber include high strength, flexibility and the ability to maintain its volume under compressive loading. Mechanical properties of concrete can also be adversely affected by the use of vulcanized rubber in concrete [6-11]. A lot of studies have been conducted for partial replacement of mineral aggregate by rubber content in concrete Low compressive and tensile strength as compared to normal concrete was reported by the addition of rubber particles in concrete [1-5]. High porosity of mix and weak bonding between concrete and rubber results in reduced concrete compressive strength due to rubber content. The jacketing of rubberized concrete (RuC) by FRP can recover the compressive strength loss due to rubber content.
External confinement of concrete columns by fiber reinforced polymer (FRP) is becoming increasingly popular in the construction field [12-14]. High tensile strength and stiffness of FRP jackets can increase the load capacity of concrete members. Many researches have shown the potential of using FRP jackets to confine concrete columns. The combination of FRP and rubberized concrete $(\mathrm{RuC})$ may result in new type of structural material having high strength and deformability. A very few number of researches have been conducted to investigate the behavior of FRP confined RuC. Li et al. [15] conducted experiments for FRP confined rubberized concrete having $15 \%$ rubber content as a replacement material. The results indicated higher compressive strength enhancement $(23 \%)$ as compared to conventional concrete. The enhancement in axial strains of fiber reinforced rubberized concrete $(\mathrm{FRuC})$ was $200 \%$ as compared to conventional concrete specimen. Youssf et al. [16] also used FRP confinement for RuC 
cylinders having 20\% rubber content. An increase of 29 and $15 \%$ was reported for axial strength and strains, respectively. Raffoul et al. [7] investigated the effect of Aramid Fiber Reinforced Polymer (AFRP) wraps on the strength and deformability of rubberized concrete. It was concluded that external confinement for RuC is highly effective for structural applications and can be used as an alternative to conventional concrete. Fig. 1 shows the confinement pressure mechanism for FRP confined concrete [17].

Extensive experimental and analytical researches have been conducted to investigate the behavior of FRP confined concrete. A lot of confinement models have been proposed in terms of axial compressive strength and stress-strain behavior [18, 19]. Empirical models have been developed to predict the strength of columns confined by FRP composites. The ductility and load enhancement capacity are addressed in detail by the available North American and European design codes. North American design codes include Canadian Standard Association (CSA-S806-02), American Concrete Institute (ACI 440.2R-2008) and Intelligent Sensing for Innovative Structures Canada ISIS MO4 2001 whereas European codes include Fédération Internationale du Béton fib Bulletin-14 and Concrete Society TR-55 [20-22].

This research investigates the combination of $\mathrm{RuC}$ and FRP jackets to develop a high strength and deformable concrete (new structural material). It is a well-known fact that addition of rubber content in concrete mix leads to increased lateral dilation of concrete. This lateral dilation can be further exploited by carbon fiber reinforced polymer (CFRP) confinement. The experimental strength test results were compared with the existing strength models and design guidelines. An analysis oriented strength model was proposed to predict the confined strength CFRP

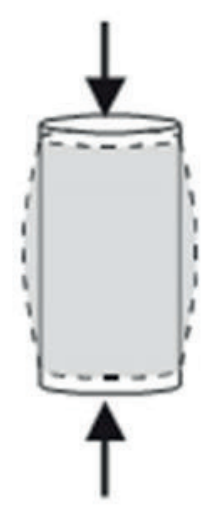

FRP-Confined concrete

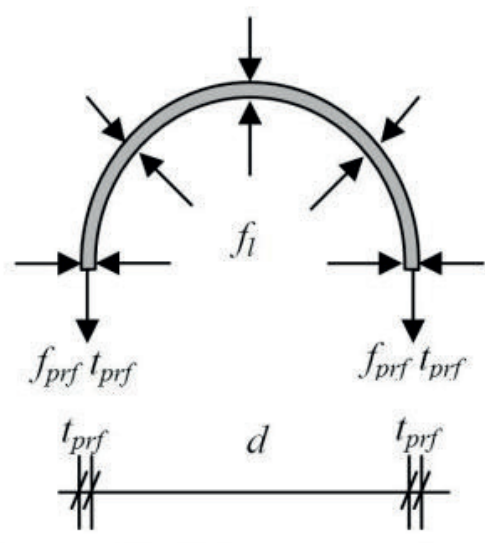

Confining pressure
Fig. 1 Confinement pressure mechanism for FRP confined concrete[17] confined rubberized concrete. The research findings will definitely assist the research community for using CFRP confined rubberized concrete in engineering applications.

\section{State of the art review of the existing codes}

A lot of confinement models have been proposed and stressstrain analysis has been done. Empirical models have been developed to predict the strength of columns confined by FRP composites [18]. This paper does not include design guidelines provided by Japanese design code because only concentric loading is covered in detail in this paper. Moreover, concentric loading is not specifically addressed in JSCE (Japan Society of Civil Engineers). The ductility and load enhancement capacity are addressed in detail by the available North American and European design codes. North American design codes include Canadian Standard Association (CSA-S806-02), American Concrete Institute (ACI 440.2R-2008) and Intelligent Sensing for Innovative Structures Canada ISIS MO4 2001 whereas European codes include Fédération Internationale du Béton (fib) Bulletin-14 and Concrete Society TR-55.

The design codes covered in this section are North American and European design codes for confinement of columns by FRP composite. North American design codes include Canadian Standard Association (CSA-S806-02), American Concrete Institute (ACI 440.2R-2008) and Intelligent Sensing for Innovative Structures Canada ISIS MO4 2001 whereas European codes include Fédération Internationale du Béton (fib) Bulletin-14 and Concretee Society TR-55. Tables 1 and 2 show the safety factors and limitations for each design code mentioned in this paper.

\subsection{ACI design guideline}

The ACI design code is based on the equations of Mander et al., 1988 for RC columns confined by steel jackets. More discussion on these models and their future development is provided by fib design code. The confined compressive strength equation proposed by ACI design guideline is based on compression and bending effects on the FRP

Table 1 Strength reduction and safety factors for design codes

\begin{tabular}{lcc}
\hline Design codes & Reduction factors (Strength) & $\begin{array}{c}\text { Safety factors } \\
\text { (Materials) }\end{array}$ \\
\hline ACI 440.2R-08 & 0.70 for ties & \\
0.75 for spirals & -- & 0.60 to 0.85 \\
CSA & -- & -- \\
ISIS & -- & 0.75 to 1.50 \\
CS & -- & \\
\hline
\end{tabular}


Table 2 Limitations and model type for design guideline codes

\begin{tabular}{|c|c|c|}
\hline Design codes & Limitations & Model Type \\
\hline ACI $440.2 \mathrm{R}-08$ & $\begin{array}{c}\mathrm{h} / \mathrm{b} \leq 900 \mathrm{~mm} \\
\mathrm{~h} / \mathrm{w}<1.5 \\
\text { Axial concentric loading } \\
\text { Corner radius } \geq 13 \mathrm{~mm}\end{array}$ & $\begin{array}{l}\text { Strength } \\
\text { Maximum } \\
\text { strain }\end{array}$ \\
\hline CSA S806-02 & $\begin{array}{c}\mathrm{h} / \mathrm{b} \leq 900 \mathrm{~mm} \\
\mathrm{~h} / \mathrm{w}<1.5 \\
\text { Axial concentric loading } \\
\text { Corner radius } \geq 13 \mathrm{~mm}\end{array}$ & 0.60 to 0.85 \\
\hline ISIS MO4-2001 & -- & -- \\
\hline CS TR-55 & $\begin{array}{l}\qquad \mathrm{h} / \mathrm{w} \leq 1.5 \\
\text { Axial concentric loading } \\
\text { Corner radius } \geq 15 \mathrm{~mm}\end{array}$ & 0.75 to 1.50 \\
\hline fib Bulletin-14 & Axial concentric loading & 1.15 to 1.50 \\
\hline
\end{tabular}

confined column. ACI code suggests Eq. (1) [25] following equations to predict the confined strength values of columns confined by FRP composites. Pu is the ultimate load capacity for columns wrapped by FRP composites [23, 24].

$P_{u}=0.85 f_{c c^{\prime}}\left(A_{g}-A_{s t}\right)+f_{y} A_{s t}$,

where

$$
\begin{aligned}
& P_{u}=\text { Axial capacity } \\
& f_{c c^{\prime}}=\text { Confined strength } \\
& A g=\text { Total area of wrapped concrete section } \\
& A_{s t}=\text { Longitudinal reinforcement area } \\
& F_{y}=\text { Yield strength of longitudinal reinforcement }
\end{aligned}
$$

Fig. 2 shows the typical FRP confined stress and strain behavior [18].

ACI proposed Eq. (2) to predict the confined strength and lateral confinement pressure is as follows:

$$
f_{c c^{\prime}}=f_{c^{\prime}}+3.3 k_{a} f_{1} \text {. }
$$

The pressure applied by wrapped FRP is indicated in Eq. (3)

$$
f_{1}=\frac{2 \varepsilon_{f e} E_{f} n t_{f}}{D}
$$

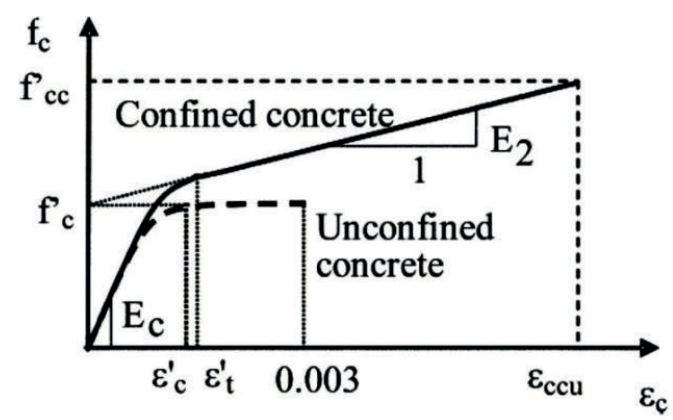

Fig. 2 ACI stress-strain model for FRP confined concrete columns [18] where

$f_{c^{\prime}}=$ Compressive strength of concrete without confinement

$f_{1}=$ Pressure applied by wrapped FRP sheets

$n=$ number of sheet layers for FRP confinement

$t_{f}=$ Cumulative FRP sheet thickness

$E_{f}=$ FRP Elastic Modulus

$\varepsilon_{f e}=$ Effective strain of wrapped FRP sheets $=k_{e} \times \varepsilon_{f u}$

\subsection{CSA code}

CSA-Canadian Standard Association CAN/CSA-S806-02 is the North American design guideline code [21]. The ultimate load by FRP confined columns can be calculated from the equations mentioned in this section. These equations can predict the load capacity of columns with FRP composites as well as the strain and ductility values for the concrete cylinder wrapped with the FRP composite. Fig. 3 shows the overlap regions for FRP confinement for columns [19].

The confined axial capacity of FRP wrapped columns is indicated in Eq. (4) $[25,26]$.

$$
f_{c c^{\prime}}=0.85 f_{c^{\prime}}+k_{1} k_{s} f_{1}
$$

The parameter k1 indicated in Eq.4 is measured by the following Eq. (5) [21].

$k_{1}=6.7\left(f_{1}\right)^{-0.17}$

The parameter ks in Eq.4 [25] show the shape factor. The external confinement pressure by FRP wrapping $\left(f_{1}\right)$ is indicated in Eq. (6) [21].

$f_{1}=\frac{2 n t_{f} \varepsilon_{f e} E_{f}}{D}$

\subsection{ISIS design guideline}

Intelligent Sensing for Innovative Structures Canada (ISIS MO4 2001) is a North American design code. This design code was introduced in 2001 and provides equations to predict the strength of columns confined by FRP laminates. The design equations also include ductility and strength enhancement capacity formulas. The strain and ultimate

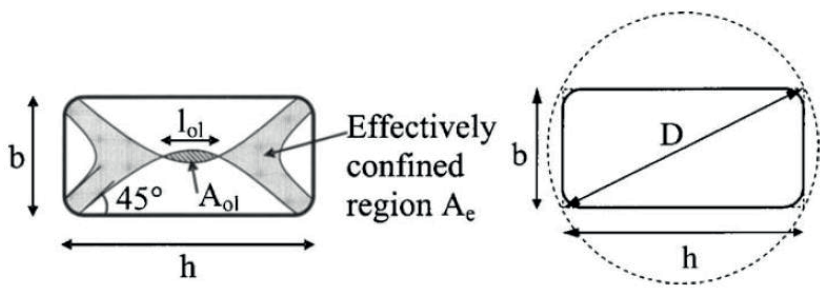

Fig. 3 FRP confinement overlap regions [19] 


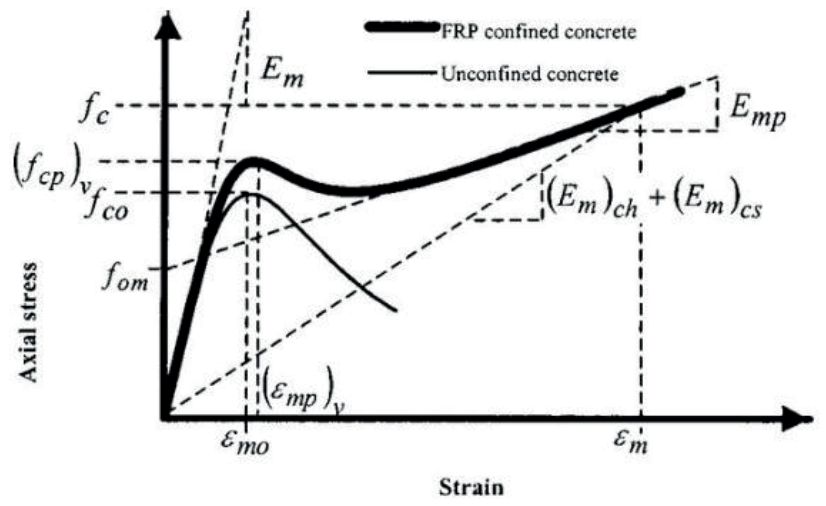

Fig. 4 Axial stress-strain curve for unconfined and FRP confined concrete [26]

load capacity can be found out by the equations mentioned in this section [24]. Fig. 4 shows the stress-strain curve for concrete with and without FRP confinement [26].

The Eq. 7 provides the confined strength value of column wrapped by FRP composites [24, 25].

$f_{c c^{\prime}}=f_{c^{\prime}}\left(1+\alpha_{p c} \omega_{w}\right)$,

where

$f_{c c^{\prime}}=$ Confined strength

$\alpha_{p r}=$ performance indication paramter

$\omega_{w}=$ Volumetric ratio

$\omega_{w}$ is dependent on confined pressure and unconfined compressive strength of concrete as indicated in Eq. (8) (ISIS MO4 2001).

$\omega_{w}=\frac{f_{1}}{f_{c^{\prime}}}$,

where confinement pressure exerted by FRP sheets is denoted by $f_{1}$ and is calculated by the Eq. (9) $[25,27]$.

$f_{1}=\frac{2 N_{b} f_{f r p u} t_{f r p}}{D_{g}}$,

where

$N_{b}=$ number of sheet layers for FRP confinement

$f_{\text {frpu }}=$ Pressure applied by wrapped FRP sheets

$t_{f r p}=$ Cumulative FRP sheet thickness

$D_{g}=$ Section diameter

Coefficient $f_{1}$ should be higher than $4 \mathrm{MPa}$ as suggested in the code [1].

\subsection{CS design code}

This European design code (Concrete Society Technical Report TR-55) includes equations to predict ultimate strength of columns confined by FRP composites. The details for confinement are covered in this section. The strength enhancement depends on number of factors like unconfined concrete strength, number FRP layers, diameter of the cross-section and elastic modulus of the FRP composite. The confinement model for CSA is based upon linear branch followed by ascending smooth branch for the stress-strain curve.

The following equation can predict the strength of columns wrapped by FRP composites.

$f_{c c^{\prime}}$ is given by the Eq. $(10)[25,28]$.

$f_{c c^{\prime}}=f_{c u}^{*}+0.05\left(\frac{2 n t_{f}}{D}\right) E_{f}$,

where $f_{c u}^{*}=$ Unconfined strength

Eq. (11) shows the limitation whereas Eq. (12) refers to the unconfined strength of concrete.

$\frac{2 n t_{f} E_{f}}{D\left(f_{c}^{\prime}\right)^{2}}>0.183\left(\mathrm{~mm}^{2} / \mathrm{N}\right)$,

$f_{c u}^{*}=\frac{f_{c^{\prime}}}{0.8}$,

where

$f_{c^{\prime}}=$ unconfined strength of concrete (without wrap)

$f_{c c^{\prime}}=$ Confined strength

$f_{c u}^{*}=$ Reduced strength after strength reduction parameter

$n=$ number of sheet layers for FRP confinement

$t_{f}=$ Cumulative FRP sheet thickness

$D=$ Section diameter

\section{5 fib design guideline}

The European design code includes fib Technical Report (Approximate and Exact Methods). This section provides detailed confinement equations to calculate the stress and strain of FRP confined concrete [29].

\subsubsection{Approximate approach (fib code)}

The Eq. (13) is proposed by fib to predict the confined compressive strength whereas the confinement pressure is shown in Eq. (14) [25, 30]. Volumetric ratio of FRP reinforcement is shown in Eq. (15) [25].

$f_{c c^{\prime}}=f_{c}^{\prime}\left(0.2+3 \sqrt{\frac{f_{1}}{f_{c^{\prime}}}}\right)$,

$f_{1}=\frac{1}{2} k_{e} \rho_{f} E_{f} \varepsilon_{f u}$,

where

$k_{e}=$ shape parameter of confinement

$\varepsilon_{f u}=$ tensile strength of FRP wrap

$E_{f}=$ Modulus of elasticity for FRP confinement 
$b_{f}=$ width of the sheet

$s=$ reduction parameter

$n=$ number of sheet layers for FRP confinement

$\rho_{f}=$ volumetric ratio of sheet

$\rho_{f}=\frac{4 n t_{f}}{10}\left(\frac{b_{f}}{s}\right)$ for circular sections

\subsubsection{Exact approach (fib code)}

The lateral confinement pressure $\left(f_{1}\right)$ can be found out by the Eq. (16) [29]. The volumetric ratio, the elastic modulus of concrete, confinement coefficient and confined elastic modulus are shown in Eqs. (17)-(20), respectively [25].

$f_{1}=\frac{1}{2} k_{e} \rho_{f} E_{f} \varepsilon_{f u}$,

where

$k_{e}=$ shape parameter of confinement

$\varepsilon_{f u}=$ tensile strength of FRP wrap

$E_{f}=$ Modulus of elasticity for FRP confinement

$\rho_{f}=$ volumetric ratio of sheet

$\rho_{f}=\frac{4 n t_{f}}{10}\left(\frac{b_{f}}{s}\right)$ for circular sections

$E_{c}=4730 \sqrt{f_{c}^{\prime}}$

$\beta=\frac{5700}{\sqrt{f_{c}^{\prime}}}-500$

$E_{c c}^{*}=\frac{f_{c c^{\prime}}^{*}}{\epsilon_{c c}^{*}}$

The Eq. (21) was proposed by fib to predict the confined compressive strength [25, 29]. Confined strain, secant elastic modulus, confined strain, and confined compressive strength is shown in Eqs. (22)-(25), respectively [25].

$$
\begin{aligned}
& f_{c c^{\prime}}^{*}=f_{c}^{\prime}\left[2.254 \sqrt{1+7.94 \frac{f_{l}}{f_{c}^{\prime}}}-2 \frac{f_{l}}{f_{c}^{\prime}}-1.254\right] \\
& \epsilon_{c c}^{*}=\in_{c}\left[1+5\left(\frac{f_{c c^{\prime}}^{*}}{f_{c}^{\prime}}-1\right)\right] \\
& E_{\mathrm{sec}, u}=\frac{E_{c}}{1+2 \beta \varepsilon_{f u}} \\
& \in_{c c}=\in_{c c}^{*}\left[\frac{E_{c c}^{*}\left(E_{c}-E_{\mathrm{sec}, u}\right)}{E_{\mathrm{sec}, u}\left(E_{c}-E_{c c}^{*}\right)}\right]^{1-\frac{E_{c c}^{*}}{E_{c}}} \\
& f_{c c}^{\prime}=E_{\mathrm{sec}, u} \mathrm{x} \varepsilon_{c c}
\end{aligned}
$$

where

$E_{\mathrm{sec}, u}=$ Secant modulus of elasticity for concrete

$f_{c^{\prime}}=$ unconfined strength of concrete(without wrap)

$b_{f}=$ width of the sheet

$s=$ pitch parameter

$t_{f}=$ Cumulative FRP sheet thickness

$n=$ number of sheet layers for FRP confinement

\section{Materials}

\subsection{Rubber and concrete}

All mixes were produced using Portland Limestone Cement having 10 percent limestone according to ASTM C1157. Alternative binder materials like Silica Fume and Pulverized Fly Ash (PFA) were also used. The fine aggregate were medium grade river washed local sand from Chengdu, Sichuan having size from 0 to $5 \mathrm{~mm}$, specific gravity 2.60 and water absorption $1.20 \%$, respectively. Coarse aggregates were round and river washed gravels from Chengdu, Sichuan having size 5-10 and 10 to $20 \mathrm{~mm}$, respectively. Two types of commercial water reducing admixtures were used.

The rubber particles in this research study were used to replace: a) fine aggregate 0 to 50 percent, b) coarse aggregate 0 to 50 percent and c) fine and coarse aggregate 0 to 50 percent by volume. The rubber particles were obtained from mechanical shredding of tires with traces of contamination. The rubber particles were divided into a) fine particles 0 to $5 \mathrm{~mm}$, b) coarse particles 5-10 $\mathrm{mm}$ and $10-20 \mathrm{~mm}$. Fine particles were replaced by fine aggregate (sand) and coarse rubber particles by coarse aggregates, respectively. Fig. 5 shows the particle size distribution of rubber aggregates determined according to ASTM C136.

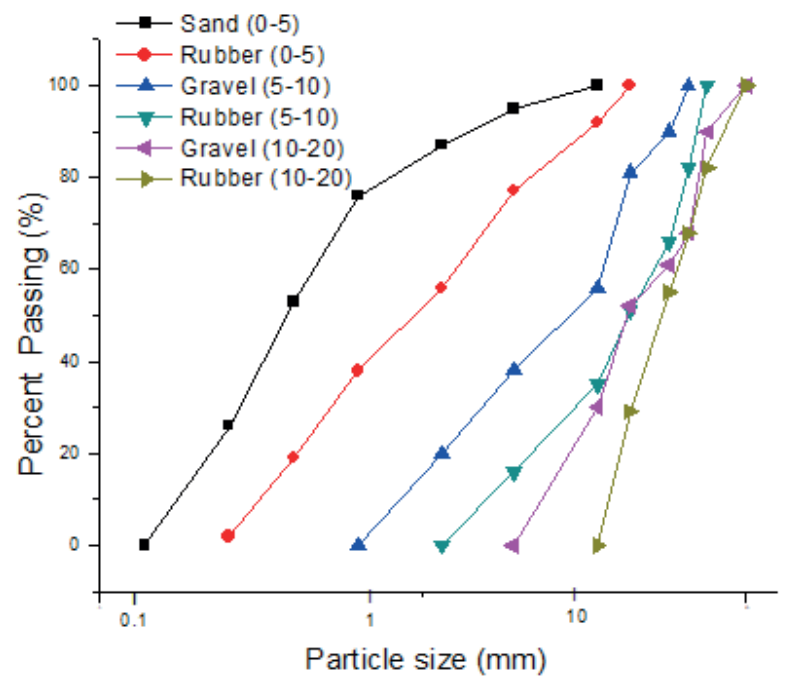

Fig. 5 Particle size distribution of mineral aggregates and rubber 
Table 3 shows the physical properties of rubber and mineral aggregates. The density, water absorption, flakiness index and bulk density were obtained using BS EN 1097-3, respectively. It is worth to note that these tests were not possible on fine rubber $(0-5 \mathrm{~mm})$ as these floats in water and stick to each other due to inter-particular forces.

\subsection{Mix design}

A typical bridge pier mix design with $40 \mathrm{MPa}$ target strength was used in this research study. The previous researches clearly show that large volume of rubber in concrete can lead to unstable mix with high levels of segregation and poor cohesion. This typical bridge pier mix design was selected so that the rubberized concrete can be used in the applications where vibration damping or energy dissipation is required. Water to binder ratio of 0.35 was used for the selected mix. Rubber particles were varied as 1) 0 to 50 percent replacement for Fine Aggregate 2) 0 to 50 percent replacement for coarse aggregate 3) 40 to 50 percent replacement for both fine and coarse aggregates. Carbon Fiber reinforced polymer (CFRP) confinement was provided in each group. The specimens with 50 percent fine and coarse rubber replacement were wrapped with CFRP sheets for Group 1 and 2, respectively. Similarly, the cylinders with 50 percent fine \& coarse rubber replacement were provided CFRP confinement for Group 3. This percentage (50\%) for FRP confinement was selected because the concrete having more rubber content exhibits higher lateral dilation which can further improve confinement by FRP jackets.

The concrete constituents were mixed as 1) rubber particles and mineral aggregates were mixed for 30 seconds. The rubber particles were used as received whereas; the mineral aggregates were saturated surface dry. 2) water was mixed in two intervals 3 ) the mix was allowed to rest for around 3 minutes 4) the binder materials (Silica Fume, Fly Ash and Cement) were added and then the remaining water was poured followed by the addition of admixtures in the mix 5) the concrete was mixed for approximately three minutes.

The cylinders were cast in two layers and vibrated using vibration table for around 20 seconds per layer. Later, the specimens were covered with plastic sheets and were de-molded after 24 hours. The specimens were put for curing in curing bath tank for 28 days. Table 4 shows the mix proportions and quantity of the materials. Table 5 represents the FRP confinement for rubberized concrete specimens.

Table 3 Physical properties of mineral aggregate and rubber

\begin{tabular}{|c|c|c|c|c|c|}
\hline Material size (mm) & Apparent density $\left(\mathrm{g} / \mathrm{cm}^{3}\right)$ & Oven dry density $\left(\mathrm{g} / \mathrm{cm}^{3}\right)$ & Water absorption (\%) & Specific gravity & Bulk density $\left(\mathrm{g} / \mathrm{cm}^{3}\right)$ \\
\hline Rubber (0-5) & 0.78 & -- & -- & -- & 0.42 \\
\hline Rubber (5-10) & $1.08-1.24$ & $1.0-1.10$ & $4.90-7.90$ & 1.08 & 0.46 \\
\hline Rubber (10-20) & 2.60 & 2.54 & $0.78-1.26$ & 1.08 & 0.48 \\
\hline Sand $(0-5)$ & 2.60 & 2.54 & 0.5 & 1.08 & 1.74 \\
\hline Gravel (5-10) & 2.67 & 2.56 & 1.22 & 2.60 & 1.48 \\
\hline
\end{tabular}

Table 4 Mix design of concrete cylinders*

\begin{tabular}{|c|c|c|c|c|c|c|c|c|c|c|}
\hline Group & Designation & $\begin{array}{l}\text { Cement } \\
\left(\mathrm{kg} / \mathrm{m}^{3}\right)\end{array}$ & $\begin{array}{l}\text { Silica fume } \\
\left(\mathrm{kg} / \mathrm{m}^{3}\right)\end{array}$ & $\begin{array}{l}\text { Fly ash } \\
\left(\mathrm{kg} / \mathrm{m}^{3}\right)\end{array}$ & $\begin{array}{c}\text { F.A. } \text { A }^{* 1} \\
\left(\mathrm{~kg} / \mathrm{m}^{3}\right)\end{array}$ & $\begin{array}{c}\text { C. } A^{* 2} \\
\left(\mathrm{~kg} / \mathrm{m}^{3}\right)\end{array}$ & $\begin{array}{l}\text { Rubber } \\
\left(\mathrm{kg} / \mathrm{m}^{3}\right)\end{array}$ & $\begin{array}{l}\text { Water } \\
\left(1 / \mathrm{m}^{3}\right)\end{array}$ & $\begin{array}{c}\text { Plasticizer } \\
\left(1 / \mathrm{m}^{3}\right)\end{array}$ & $\begin{array}{l}\text { S.P } P^{* 3} \\
\left(1 / \mathrm{m}^{3}\right)\end{array}$ \\
\hline \multirow{6}{*}{ G-1 } & $\mathrm{C}$ & 1.36 & 0.17 & 0.17 & 3.28 & 4.004 & 0 & 0.6 & 0.01 & 0.0204 \\
\hline & F-10 & 1.36 & 0.17 & 0.17 & 2.952 & 4.004 & 0.328 & 0.6 & 0.01 & 0.0204 \\
\hline & $\mathrm{F}-20$ & 1.36 & 0.17 & 0.17 & 2.624 & 4.004 & 0.656 & 0.6 & 0.01 & 0.0204 \\
\hline & F-30 & 1.36 & 0.17 & 0.17 & 2.296 & 4.004 & 0.984 & 0.6 & 0.01 & 0.0204 \\
\hline & $\mathrm{F}-40$ & 1.36 & 0.17 & 0.17 & 1.968 & 4.004 & 1.312 & 0.6 & 0.01 & 0.0204 \\
\hline & $\mathrm{F}-50$ & 1.36 & 0.17 & 0.17 & 1.64 & 4.004 & 1.64 & 0.6 & 0.01 & 0.0204 \\
\hline \multirow{5}{*}{ G-2 } & C-10 & 1.36 & 0.17 & 0.17 & 2.952 & 4.004 & 0.328 & 0.6 & 0.01 & 0.0204 \\
\hline & $\mathrm{C}-20$ & 1.36 & 0.17 & 0.17 & 2.624 & 4.004 & 0.656 & 0.6 & 0.01 & 0.0204 \\
\hline & $\mathrm{C}-30$ & 1.36 & 0.17 & 0.17 & 2.296 & 4.004 & 0.984 & 0.6 & 0.01 & 0.0204 \\
\hline & C-40 & 1.36 & 0.17 & 0.17 & 1.968 & 4.004 & 1.312 & 0.6 & 0.01 & 0.0204 \\
\hline & C-50 & 1.36 & 0.17 & 0.17 & 1.64 & 4.004 & 1.64 & 0.6 & 0.01 & 0.0204 \\
\hline \multirow{2}{*}{ G-3 } & CF-40 & 1.36 & 0.17 & 0.17 & 1.968 & 2.404 & 1.912 & 0.6 & 0.01 & 0.0204 \\
\hline & CF-50 & 1.36 & 0.17 & 0.17 & 1.64 & 2.002 & 3.642 & 0.6 & 0.01 & 0.0204 \\
\hline
\end{tabular}

$* 1$ F.A represents the fine aggregates, $* 2$ C.A shows coarse aggregates, and *3 S.P represents super plasticizer. 


\subsection{Physical and mechanical properties of FRP}

The physical and mechanical properties of unidirectional CFRP fabric and cured laminate sheets are shown in Table 6. The tensile strength and elastic modulus of unidirectional CFRP fabric were $4100 \mathrm{MPa}, 231000 \mathrm{MPa}$, respectively. Percentage elongation for CFRP fabric as provided by the manufacturer was $1.7 \%$. Standard value of tensile strength, tensile Elastic Modulus, elongation and density for cured laminate jackets were $894 \mathrm{MPa}, 65402 \mathrm{MPa}$, $1.7 \%, 1.8 \mathrm{~g} / \mathrm{cc}$, respectively. The surface of specimens was cleaned by brush to get rid of sand and other impurities.

\begin{tabular}{|c|c|c|c|c|c|}
\hline Group & Designation & $\begin{array}{c}\text { Fine } \\
\text { rubber }(\%)\end{array}$ & $\begin{array}{c}\text { Coarse } \\
\text { rubber }(\%)\end{array}$ & FRP & $\mathrm{n}^{*}$ \\
\hline \multirow{7}{*}{ G-1 } & $\mathrm{C}$ & -- & -- & No & -- \\
\hline & F-10 & 10 & -- & No & -- \\
\hline & $\mathrm{F}-20$ & 20 & -- & No & -- \\
\hline & $\mathrm{F}-30$ & 30 & -- & No & -- \\
\hline & $\mathrm{F}-40$ & 40 & -- & No & -- \\
\hline & F-50 & 50 & -- & No & -- \\
\hline & F-FRP(1L) & 50 & -- & Yes & 1 \\
\hline \multirow{10}{*}{ G-2 } & F-FRP(2L) & 50 & -- & Yes & 2 \\
\hline & F-FRP(3L) & 50 & -- & Yes & 3 \\
\hline & $\mathrm{C}-10$ & -- & 10 & No & -- \\
\hline & $\mathrm{C}-20$ & -- & 20 & No & -- \\
\hline & $\mathrm{C}-30$ & -- & 30 & No & -- \\
\hline & $\mathrm{C}-40$ & -- & 40 & No & -- \\
\hline & $\mathrm{C}-50$ & -- & 50 & No & -- \\
\hline & C-FRP(1L) & -- & 50 & Yes & 1 \\
\hline & C-FRP(2L) & -- & 50 & Yes & 2 \\
\hline & C-FRP(3L) & -- & 50 & Yes & 3 \\
\hline \multirow{5}{*}{ G-3 } & CF-40 & 40 & 40 & No & -- \\
\hline & $\mathrm{CF}-50$ & 50 & 50 & No & -- \\
\hline & CF-FRP(1L) & 50 & 50 & Yes & 1 \\
\hline & CF-FRP(2L) & 50 & 50 & Yes & 2 \\
\hline & CF-FRP(3L) & 50 & 50 & Yes & 3 \\
\hline
\end{tabular}

$*_{n}$ represents the number of FRP layers.

Table 6 Physical and mechanical properties of unidirectional CFRP fabric and cured laminate sheets

\begin{tabular}{lcc}
\hline Design codes & $\begin{array}{c}\text { CFRP fabric } \\
\text { value }\end{array}$ & Composite laminate \\
\hline $\begin{array}{l}\text { Primary Fiber Direction } \\
\text { Standard Value of Tensile } \\
\text { strength (MPa) }\end{array}$ & Unidirectional & -- \\
$\begin{array}{l}\text { Tensile Elastic Modulus } \\
(\mathrm{MPa})\end{array}$ & 4100 & 894 \\
Elongation (\%) & 231000 & 65402 \\
\hline
\end{tabular}

\subsubsection{FRP jacketing and testing procedure}

All the concrete specimens to be wrapped with the carbon fiber reinforced polymer were taken out of curing tank at least one week before wrapping. Unidirectional CFRP sheets were used in this research study. The carbon fiber sheets were wrapped manually around the cylinders using the wet layup technique. An overlap of $3 / 4$ inches was provided according to American Concrete Institute (ACI 318-08) in order to avoid premature failure or de-bonding of FRP sheets. Fig. 6 shows the fabrication of CFRP jackets. The surface of cylinders was checked thoroughly and was made smooth before the application of epoxy. Dust was removed with the help of a common brush and other disturbing particles were also removed at the time of application of epoxy. The two components of epoxies were mixed with recommended ratio of $4: 1$ (four parts of component $A$ and one part of component B). The epoxy fully hardened after 4-5 hours.

A total of 27 specimens were wrapped with FRP to investigate the behavior and effectiveness of FRP confinement on rubberized concrete. 1, 2 and 3 layers of FRP jackets were used. The specimens were tested under axial compression using a $3000 \mathrm{kN}$ capacity compression testing machine. Additional wrapping with $25 \mathrm{~mm}$ FRP was also provided for FRP-wrapped cylinders. The cylinders were loading up to failure using a loading rate of $0.25 \mathrm{MPa} / \mathrm{sec}$. ASTM C39 testing procedure was followed for axial compression tests [30]. Fig. 7 shows the general view of the test setup. $10 \mathrm{~mm}$ foil type electrical resistance strain gauges were attached on each specimen to measure horizontal and vertical strains. Two vertical and horizontal strain gauges located at mid height of specimens were used to measure axial as well as horizontal strains, respectively. A total of four LVDTs were used to measure axial as well as vertical

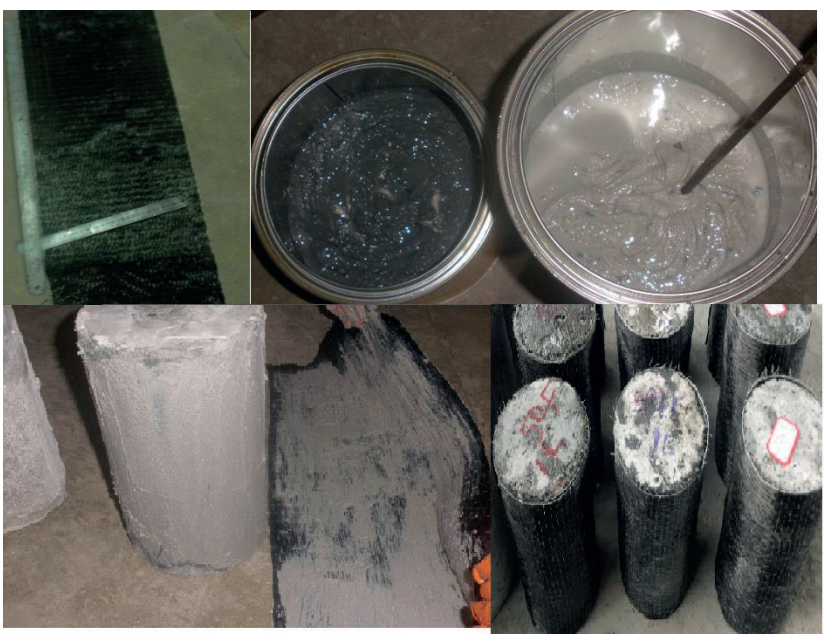

Fig. 6 Fabrication of CFRP jackets 


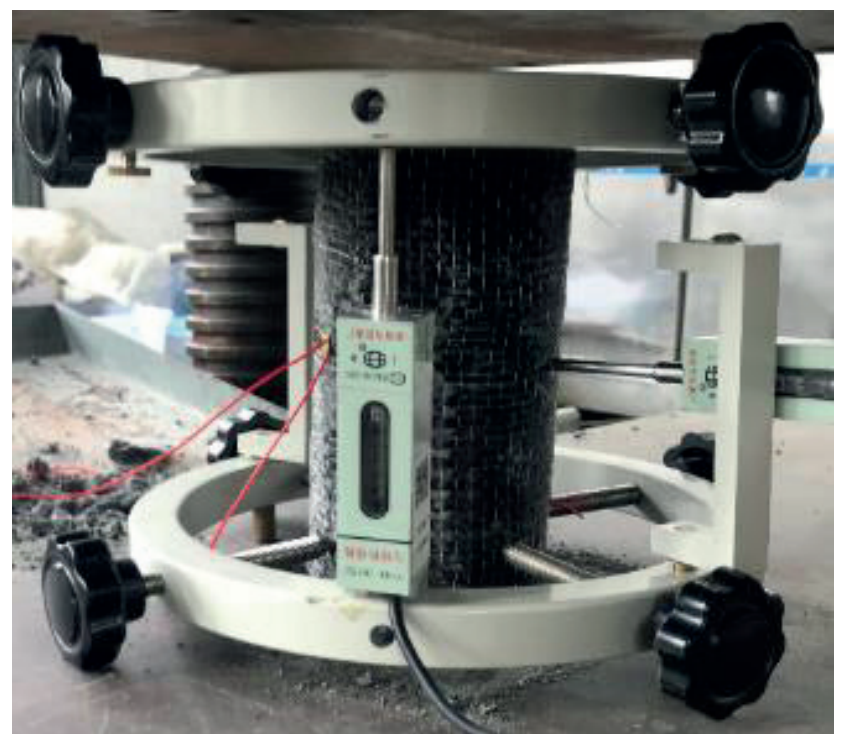

Fig. 7 General view of test setup

displacements of specimens. Two LVDTs placed in horizontal and vertical direction were fixed in a clamp especially designed for measuring displacements in the cylindrical specimens.

\section{Results and discussion}

\subsection{Failure modes}

Typical failure modes for CFRP confined RuC cylinders are shown in Fig. 8. The CFRP confined RuC cylinders for Group 1 showed ringed and localized failure of FRP jackets. Cracking sounds in FRP jackets were produced at approximately 50\% ultimate stress. Gradual failure was observed leading to rupture of FRP jackets. Similarly, ringed and localized failure of FRP jackets was observed for FRP confined RuC cylinders in Group 2 and 3, respectively. Moreover, the specimen in Group 1 showed FRP rupture at the middle and bottom section. However, most of the specimen in Group 2 and 3 failed by FRP rupture at the middle section.

\subsection{Effect of FRP layers on axial compressive strength and stress-strain behavior of RuC concrete (Experimental investigation)}

The rubber content in concrete tends to expand more than the surrounding concrete when subjected to axial compressive loading. This phenomenon results in enhanced tensile stress concentration in $\mathrm{RuC}$ resulting in lower peak axial strains and premature failure as compared to conventional concrete. It can be seen from the microstructural observation in Fig. 9 that the concrete with high rubber content (40\%) has more jagged areas and dents.

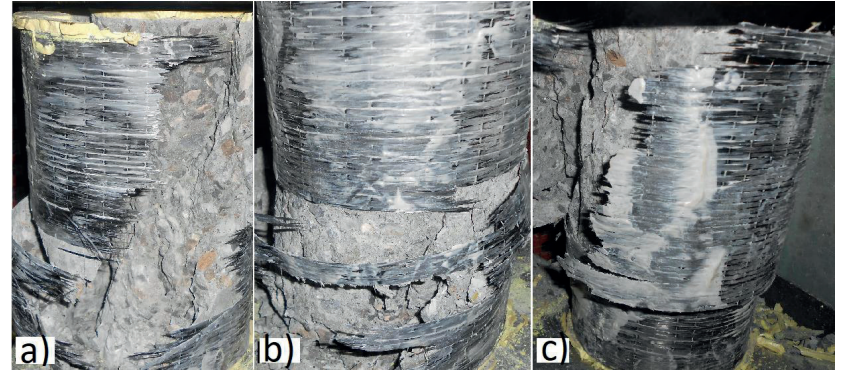

Fig. 8 Typical failure modes of CFRP confined RuC cylinders with a) fine, b) coarse and c) fine $\&$ coarse rubber replacement

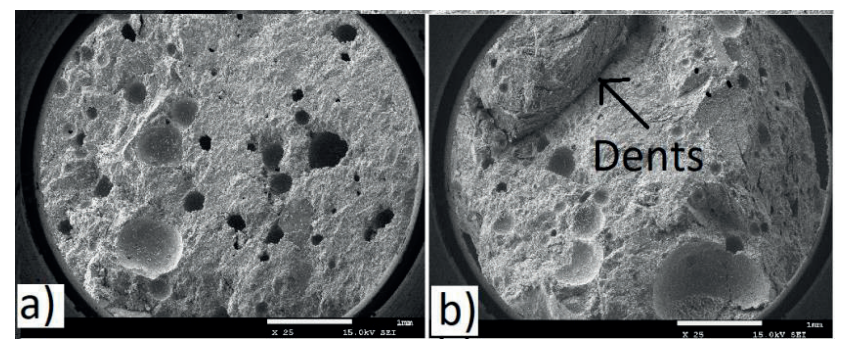

Fig. 9 SEM image analysis of concrete with a) $0 \%$ rubber content, and b) $40 \%$ coarse rubber

It's a well-known fact that the inclusion of rubber content in the concrete leads to increased lateral expansion of concrete. This lateral expansion and premature cracking of concrete also leads to low strength for rubberized concrete. This increased lateral expansion results in low compressive strength, stiffness and axial strains. Moreover, this premature lateral expansion of concrete can be exploited to develop high strength and deformable concrete. The confining pressure by FRP sheets can be activated by the high lateral expansion of RuC. The specimens with $50 \%$ rubber replacement were selected for CFRP confinement to exploit the lateral dilation of RuC cylinders.

It can be clearly seen from the Table 7 that the effectiveness of CFRP increases with number of CFRP layers. Table 7 shows the unconfined, confined strength, confinement ratio, axial and lateral strains. Confinement ratio is defined as the ratio of confined to unconfined strength of the specimen. For Group 1 cylinders, the strength increment in the range of 58 to 105 percent was observed for 1,2 and 3 layers of CFRP confinement. The axial compressive strength enhancement was more pronounced for 3 layers of CFRP confinement. Confinement ratio was observed to be 1.6 to 2.1 for 1, 2 and 3 layers of CFRP confinement. The strength increment in the range of 327 to 409 percent was recorded for 1, 2 and 3 layers of CFRP confinement (coarse aggregate replacement). Fig. 10 shows the strength enhancement ratio of CFRP confined rubberized concrete. 
Table 7 Test results for CFRP-confined rubberized concrete

\begin{tabular}{|c|c|c|c|c|c|c|c|}
\hline Test No. & $f_{c c^{\prime}}(\mathrm{MPa})$ & $\varepsilon_{c p}(\mu \varepsilon)$ & $\varepsilon_{c L p}(\mu \varepsilon)$ & $\varepsilon c \mathrm{P} / \varepsilon \mathrm{cLp}$ & $* f_{c c^{\prime}} / f_{c^{\prime}}$ & $E_{c}(\mathrm{GPa})$ & $\mu^{*}$ \\
\hline F-FRP(1L) & 30 & 2599 & 1667 & 1.55 & 1.60 & 6.46 & 2.05 \\
\hline F-FRP(2L) & 36 & 4639 & 1521 & 3.04 & 1.90 & 7.42 & 2.10 \\
\hline F-FRP(3L) & 39 & 4849 & 1773 & 2.73 & 2.01 & 15 & 2.19 \\
\hline C-FRP(1L) & 47 & 3878 & 2252 & 1.72 & 4.28 & 11.38 & 1.91 \\
\hline C-FRP(2L) & 52 & 4129 & 2278 & 1.81 & 4.73 & 13.40 & 2.25 \\
\hline C-FRP(3L) & 56 & 4310 & 1900 & 2.26 & 5.10 & 24.24 & 5.46 \\
\hline CF-FRP(1L) & 49 & 2599 & 1619 & 2.77 & 6.13 & 10.91 & 1.96 \\
\hline CF-FRP(2L) & 53 & 4539 & 1453 & 3.12 & 6.63 & 11.68 & 2.02 \\
\hline CF-FRP(3L) & 56 & 4689 & 1440 & 3.25 & 7.0 & 11.94 & 2.56 \\
\hline
\end{tabular}

* $\mu$ represents the ductility of the tested specimen.

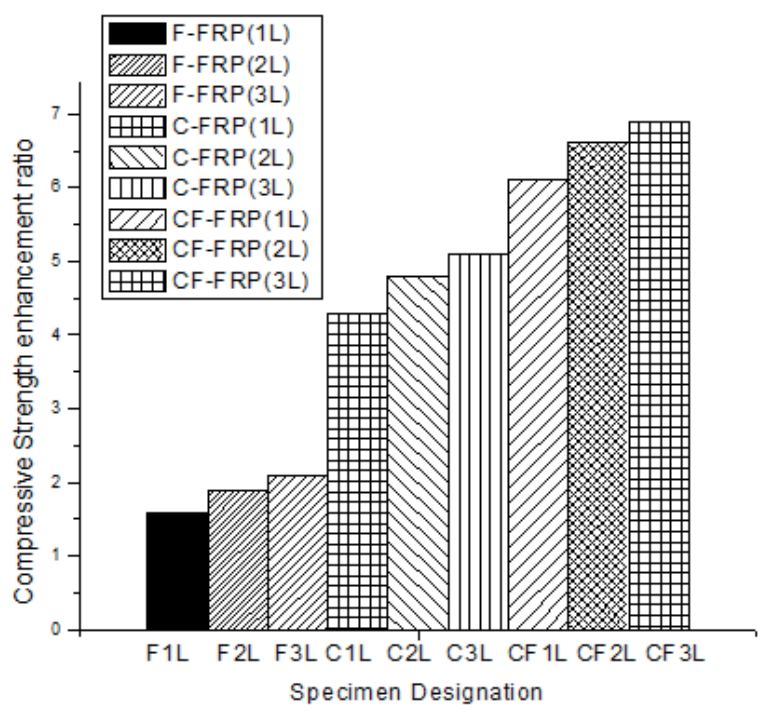

Fig. 10 Compressive strength enhancement ratio for FRP confined cylinders

It is worth to note that compressive strength was more pronounced for 3 layers of CFRP confinement. Confinement ratio in the range of 4.3 to 5.1 for 1,2 and 3 layers of CFRP confinement was recorded. Furthermore, the effect of number of FRP wraps on compressive strength of rubberized concrete for Group 3 (Fine \& Coarse aggregate replacement) can be seen from Table 7 . The strength enhancement ratio of RuC cylinders was recorded to be 6.9 for 3 layers of FRP confinement (fine \& coarse aggregate replacement). It is worth to note that the strength increment with FRP confinement was more pronounced for Group $3 \mathrm{RuC}$ cylinders (Fine \& Coarse aggregate replacement). The reason can be increased lateral dilation for Group 3 specimens. Furthermore, the axial strength enhancement up to 590 percent was recorded for 3 layers of CFRP confined rubberized concrete. It is evident from the results that confinement effectiveness of rubberized concrete increases with the increase in CFRP layers.
Table 7 also shows the axial and lateral strain data. Two vertical and horizontal strain gauges were used to measure the strain data. It is worth to mention that the rubber content increases the lateral dilation of concrete samples. Unfortunately, this lateral dilation and premature cracking results in decrease of axial compressive strength for concrete cylinders. This premature lateral expansion of concrete is attributed to high confinement pressure by fiber reinforced polymer (FRP) jackets. The confining pressure by FRP sheets can be activated by the high lateral expansion of RuC. $4689 \mu \varepsilon$ axial strain value was recorded for three layers of CFRP confinement of RuC (CF-FRP2L). It is worth to note that this behavior can be divided in to two parts:

a. An initial linear elastic curve controlled by unconfined $\mathrm{RuC}$ behavior.

b. 2nd linear section of curve controlled by FRP confinement.

$260 \%$ increase in axial strain value was recorded for 2-layer FRP confinement of CF-FRP2L concrete cylinders. It is worth to note that an increment of $330 \%$ in lateral strain was recorded for C-FRP2L specimens. The lateral dilation of RuC can be successfully exploited using 1, 2 and 3 layers of CFRP confinement.

Peak axial strains $\left(\varepsilon_{c P}\right)$ of 4639,4849 and $2599 \mu \varepsilon$ were reported from the experimental test results for the mixes F-FRP (1L), F-FRP (2L) and F-FRP (3L), respectively. This indicates an increase of 164,177 , and $48 \%$ over the corresponding plain concrete cylinders. Furthermore, the lateral strains of 1667,1521 and $1773 \mu \varepsilon$ were recorded, where an increment of 141, 120 and $157 \%$ was observed over the corresponding plain concrete cylinders. Fig. 11 and show the stress-strain values of $1 \mathrm{~L}, 2 \mathrm{~L}$ and $3 \mathrm{~L}$ CFRP-confined RuC in Group 1. Peak axial strains $\left(\varepsilon_{c P}\right)$ of 4129,3878 and $2310 \mu \varepsilon$ were reported from the experimental test results for the mixes C-FRP (1L), C-FRP (2L) and C-FRP (3L), respectively. This 
indicates an increase of 136,121 , and $32 \%$ over the corresponding plain concrete cylinders. Furthermore, the lateral strains of 2252, 2278 and $1900 \mu \varepsilon$ were recorded for lateral strains, where an increment of 29,30 and $9 \%$ was observed over the corresponding plain concrete cylinders. Fig. 12 shows the stress-strain values of $1 \mathrm{~L}, 2 \mathrm{~L}$ and $3 \mathrm{~L}$ CFRPconfined RuC in group-2. Peak axial strains of 4488, 4539 and $4689 \mu \varepsilon$ were recorded for 1, 2 and 3 layered CFRP confined RuC in Group 3, respectively. Fig 13 shows the stress-strain behavior for this group. Moreover, peak lateral strains of 1619,1453 and $1440 \mu \varepsilon$ were reported for 1,2 and 3 layers of CFRP confined RuC. This shows 317\% increase in axial strain value of 3-L (layered) CFRP confined $\mathrm{RuC}$ over corresponding unconfined RuC in Group 3 (Fig. 13). Peak axial strain of $4689 \mu \varepsilon$ for 3L CFRP confined RuC in Group 3 was recorded i.e., 103 and 80\% higher than the corresponding values in Group 1 and 2, respectively. Peak lateral strain of $1440 \mu \varepsilon$ was recorded for 3L CFRP confined $\mathrm{RuC}$ in group 3 i.e., 32 and $23 \%$ lesser than the corresponding values in Group 1 and 2, respectively.

It can be concluded that CFRP confinement successfully delayed the onset of cracking which is clear from an increase in the linear elastic portion of stress-strain curves. High lateral strains in RuC with $50 \%$ combined fine \& coarse rubber replacement resulted in high compressive strength (600\%) of CFRP confined RuC over corresponding $\mathrm{RuC}$. It has been discussed previously in the compressive strength section. It is noteworthy to mention here that the CFRP jackets can provide effective restraint to the increased lateral dilation of $\mathrm{RuC}$. The compressive strength of CFRP confined RuC is essentially dependent on the maximum confinement pressure by CFRP jackets. This confinement pressure was more successfully exploited by CFRP jackets in group 3 over the corresponding Group 1 and 2, respectively. This exploitation by FRP confinement resulted in high confined compressive strength of rubberized concrete. It is worth to mention that the $3 \mathrm{~L}$ (layer) CFRP jacketing of RuC with $50 \%$ rubber content in Group 3 was more superior to the corresponding samples in Group 1 and 2, respectively.

\subsection{Strength model}

The CFRP confined compressive strength of $\mathrm{RuC}$ from experimental test results were used to verify the accuracy of strength prediction equations of the confined strength for the strength models and two well-known international design guidelines i.e., Fédération Internationale du Béton (fib-14), and Concrete Society (CS TR.55).

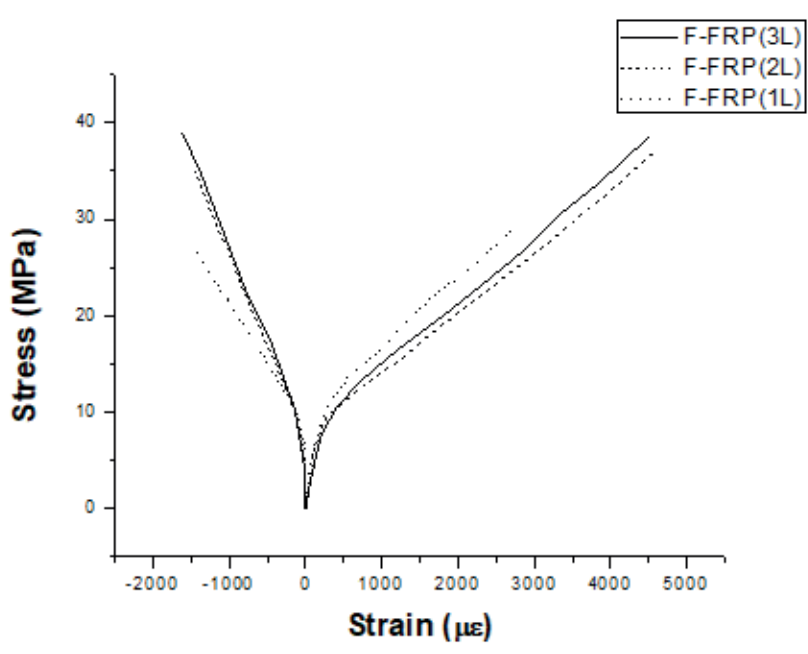

Fig. 11 Axial and lateral stress-strain plot of CFRP-confined rubberized concrete (Group 1)

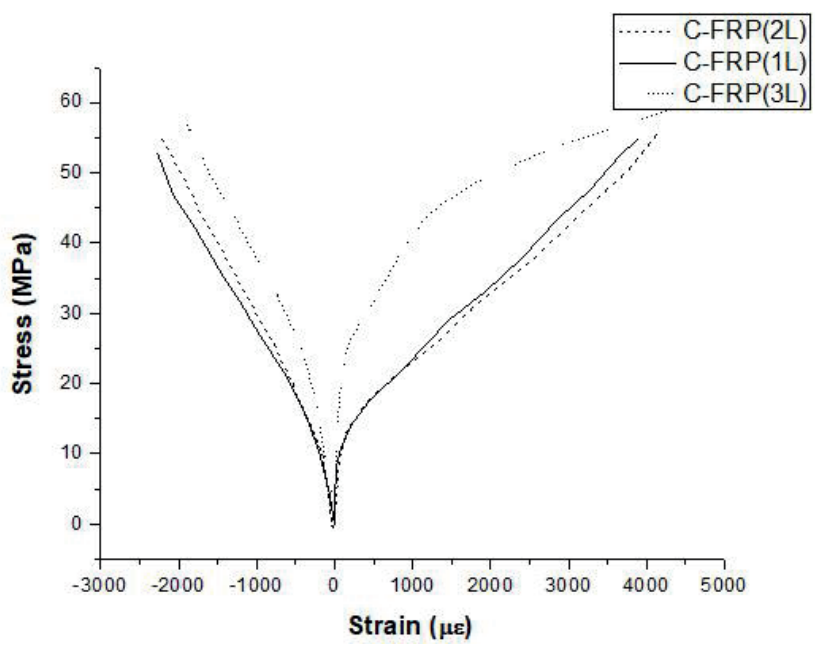

Fig. 12 Axial and lateral stress-strain plot of CFRP-confined rubberized concrete (Group 2)

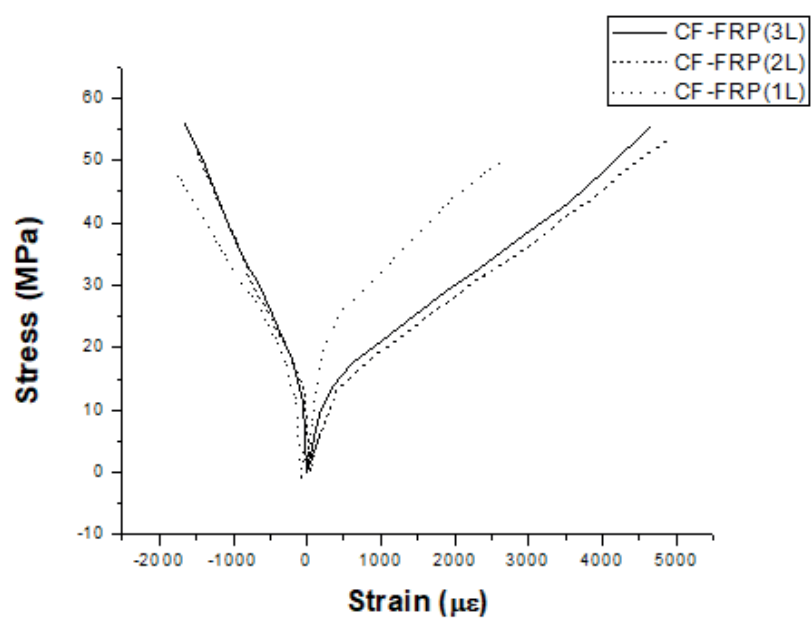

Fig. 13 Axial and lateral stress-strain plot of CFRP-confined rubberized concrete (Group 3) 
A lot of strength models are available for FRP confinement of concrete columns. Most of the existing strength models are based on the following Eq. (26) [31]. They are generally classified as design and analysis-oriented strength models.

$f_{c c}^{\prime}=f_{c o}^{\prime}+k_{1} f_{1}^{\prime}$

The parameter $f_{c c^{\prime}}, f_{c o^{\prime}}, k_{1}$ and $f_{1}$ refers to the confined strength, unconfined strength, confinement pressure and confinement coefficient. The first strength model in terms of compressive strength enhancement was proposed by Richart et al. [31]. Since then, several models were developed based on the Eq. (3). The most important parametric coefficient was $\mathrm{k} 1$ that was varied by several experimental studies [32-35]. Most of the equations developed for FRP confined circular sections are based on two parameters i.e., unconfined strength and confinement pressure [36].

Fardis et al. proposed the Eq. (27) to predict the confined strength of concrete columns by FRP [37].

$f_{c c}^{\prime}=f_{c o}^{\prime}+4.1 f_{1}$

Most recently, strength model proposed by Pham et al. is indicated in Eq. (28).

$$
f c c^{\prime}=0.7 f_{c o}^{\prime}+1.8 f_{1}+5.7 \frac{t}{d}+13
$$

The parameters $f_{c c^{\prime}}, f_{c o^{\prime}}, f_{1}, t$ and $d$ refer to the confined strength, unconfined strength, confinement pressure, thickness of FRP and diameter of the section. Table 8 shows the experimental confined compressive strength $\left(f_{c c^{\prime}}\right)$ and theoretical confinement ratios $\left(f_{c c^{\prime}} / f_{c^{\prime}}\right)$ of CFRP confined rubberized concrete.

The prediction of test results by ACI, CSA and ISIS are shown in Figs. 14-16, respectively. American Concrete Institute code provided better prediction of test results for fine rubber replacement. However, the same guideline fails to predict the confined strength for other replacement types. CSA and ISIS highly underestimated the test results.

Concrete Society Technical Report TR-55 [38] includes confinement equations to predict the theoretical strength of columns confined by FRP composites. The strength enhancement depends on number of factors like unconfined concrete strength, number FRP layers, diameter of the cross-section and elastic modulus of the FRP composite. The prediction of test results by CS and fib are shown in Figs. 17 and 18, respectively. CS proposes the following equation to predict the strength of columns wrapped by FRP composites [38]. $f_{c c^{\prime}}$ is given by the Eq. (29) [38].

$f_{c c^{\prime}}=f_{c u}^{*}+0.05\left(\frac{2 n t_{f}}{D}\right) E_{f}$,

where the parameters $f_{c c^{\prime}}, f_{c u}^{*}, n, t_{f}$ and $D$ refers to the confined compressive strength, unconfined compressive strength, number of FRP layers, thickness of FRP, and diameter of the section.

CS proposed the limit i.e., $\frac{2 n t_{f} E_{f}}{D\left(f_{c}^{\prime}\right)^{2}}>0.183\left(\mathrm{~mm}^{2} / N\right)$.

Eq. (30) [38] represents the modified unconfined compressive strength of concrete as the ratio of unconfined strength of concrete to 0.8 .

$f_{c u}^{*}=\frac{f_{c^{\prime}}}{0.8}$,

where

$f_{c u}^{*}=$ final unconfined concrete compressive strength after reduction factor

$f_{c^{\prime}}=$ unconfined concrete strength specified

The European design code includes Fédération Internationale du Béton (fib) Technical Report [19]. This design guideline suggests Eq. (31) to predict the confined compressive strength of circular concrete sections confined by FRP [19]. The confinement pressure provided by FRP jackets can be calculated from Eq. (32). The volumetric ratio of FRP confinement is shown in Eq. (33) [19].

Table 8 Performance of strength models in terms of compressive strength enhancement of CFRP confined RuC

\begin{tabular}{|c|c|c|c|c|c|c|c|c|}
\hline Test No. & CS TR-55 & fib & ACI & CSA & ISIS & Fardis et al. [35] & Pham et al. [39] & Proposed Model \\
\hline F-FRP(1L) & 1.63 & 2.11 & 1.421 & 1.315 & 1.57 & 1.51 & 1.61 & 1.88 \\
\hline F-FRP(2L) & 2.21 & 2.95 & 1.789 & 1.736 & 2.526 & 1.94 & 1.80 & 2.21 \\
\hline F-FRP(3L) & 2.68 & 3.85 & 2.263 & 2.157 & 3.526 & 2.37 & 1.99 & 2.35 \\
\hline C-FRP(1L) & 1.63 & 2.73 & 1.727 & 1.636 & 1.545 & 1.89 & 2.27 & 4.0 \\
\hline C-FRP(2L) & 2.18 & 4.19 & 2.454 & 2.363 & 2.545 & 2.63 & 2.60 & 4.27 \\
\hline C-FRP(3L) & 2.72 & 6.10 & 3 & 3.09 & 3.54 & 3.38 & 2.93 & 4.81 \\
\hline CF-FRP(1L) & 1.62 & 3.25 & 2 & 1.87 & 1.625 & 2.22 & 2.87 & 5.75 \\
\hline CF-FRP(2L) & 2.25 & 5.38 & 3 & 2.87 & 2.625 & 3.24 & 2.87 & 6.12 \\
\hline CF-FRP(3L) & 2.62 & 6.25 & 3.87 & 4 & 3.625 & 4.27 & 2.87 & 6.62 \\
\hline
\end{tabular}




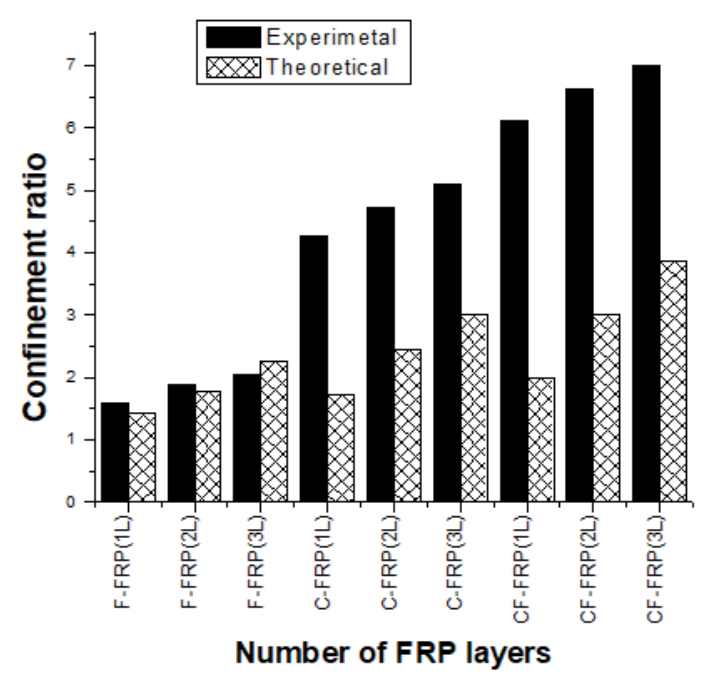

Fig. 14 Experimental versus theoretical (ACI) axial compressive strength prediction for CFRP-confined rubberized concrete

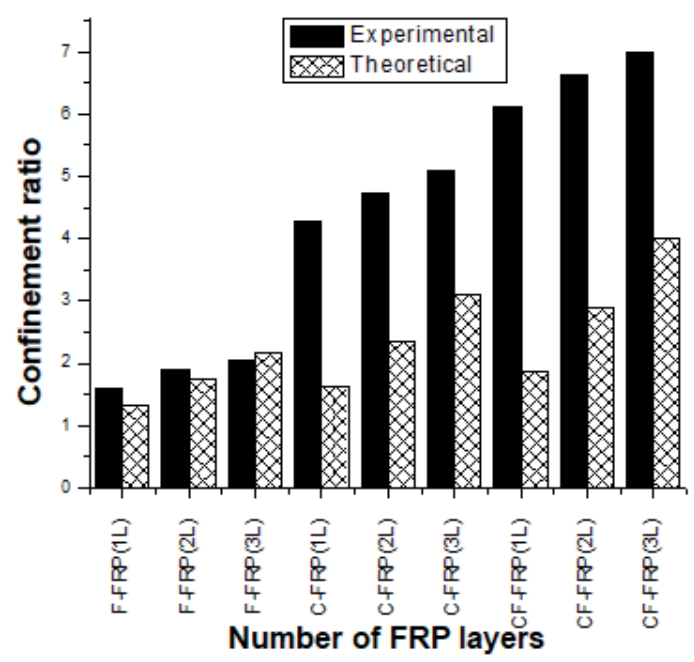

Fig. 15 Experimental versus theoretical (CSA) axial compressive strength prediction for CFRP-confined rubberized concrete

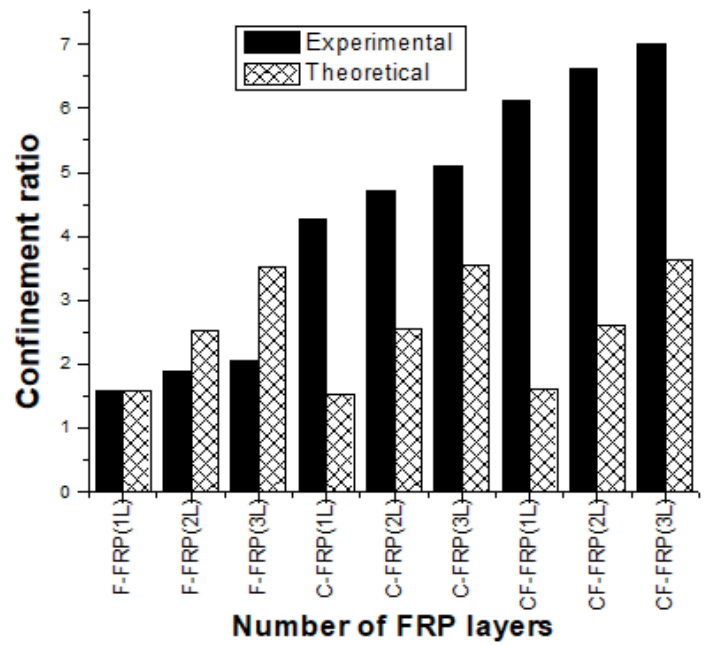

Fig. 16 Experimental versus theoretical (ISIS) axial compressive strength prediction for CFRP-confined rubberized concrete

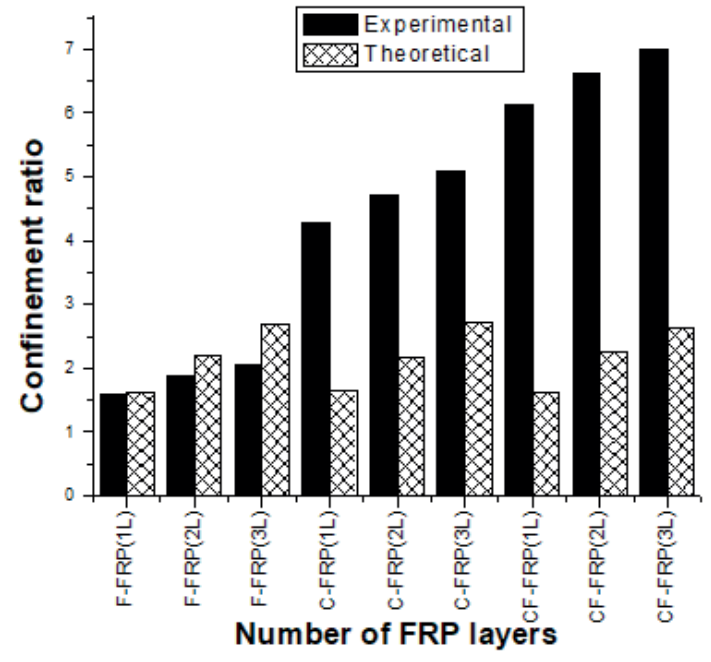

Fig. 17 Experimental versus theoretical (CS) axial compressive strength prediction for CFRP-confined rubberized concrete

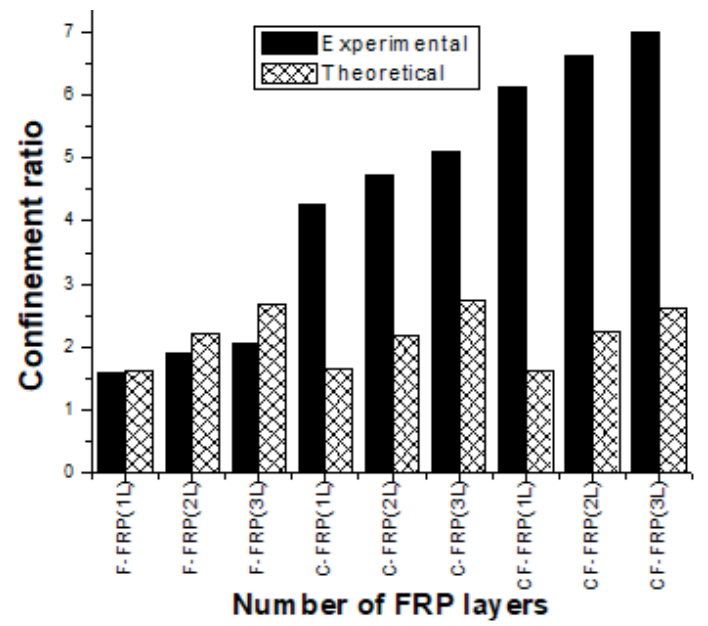

Fig. 18 Experimental versus theoretical (fib) axial compressive strength prediction for CFRP-confined rubberized concrete

$f_{c c^{\prime}}=f_{c}^{\prime}\left(0.2+3 \sqrt{\frac{f_{1}}{f_{c^{\prime}}}}\right)$

$f_{1}=\frac{1}{2} k_{e} \rho_{f} E_{f} \varepsilon_{f u}$

Where $f_{c c^{\prime}}, f_{c^{\prime}}, f_{1}, k_{e}, \rho_{f}, E_{f}$, and $\varepsilon_{f u}$ refers to the confined strength, unconfined strength, confinement coefficient, FRP ratio, elastic modulus of FRP, and ultimate tensile strain of FRP. [19].

$\rho_{\mathrm{f}}=\frac{4 n t_{f}}{10}\left(\frac{b_{f}}{s}\right)$

The strength models shown in Table 8 underestimate the test results for low unconfined strength of concrete $\left(f_{c}\right)$. However, reasonable predicted confined strength $\left(f_{c c}\right)$ values were found for higher unconfined strength of concrete $(19 \mathrm{MPa})$. This shows that the models are not adopted for lower unconfined strength of concrete. 
The concrete core tends to expand laterally when subjected to axial loading and FRP jackets restrain this expansion. Passive lateral confinement pressure is provided by the FRP jackets. The uniaxial load is converted into tri-axial load due to passive confinement provided by FRP. The behavior of conventional and rubberized concrete is different in terms of stress-strain. Moreover, rubberized concrete produces more lateral expansion as compared to conventional concrete when confined by FRP. Current models developed for FRP confined conventional concrete underestimate the confined strength of concrete $\left(f_{c c}\right)$. The analysis oriented strength model proposed by the author for CFRP confined rubberized concrete is shown in Eq. (34). The model provides reasonable results with error (\%) less than 10 .

$\frac{f_{c c}^{\prime}}{f_{c}^{\prime}}=\left[1+4.2 \frac{f_{1}}{f_{c}^{\prime}}\right]$

The proposed strength model is only valid for small number of experimental test results of CFRP confined rubberized concrete. More databases are needed to verify the strength model for wide range of unconfined strength of concrete $\left(f_{c}\right)$. The confinement mechanism of rubberized concrete is highly dependent on the unconfined strength of concrete $\left(f_{c}\right)$.

\section{Conclusions}

This paper presented the axial compressive strength test results and stress-strain behavior of developed CFRP confined rubberized concrete with enhanced strength and deformation capacity. The test results were compared with strength models and design guideline codes. The findings of the paper are:

- CFRP confinement of rubberized concrete was highly effective to improve its compressive strength. CFRP confinement of $\mathrm{RuC}$ cylinders with combined fine and coarse rubber content was superior to other replacement types. High strength increment $(600 \%)$ was recorded for 3 layer of CFRP wrapping.

\section{References}

[1] Thomas, B. S., Gupta, R. C. "A comprehensive review on the applications of waste tire rubber in cement concrete", Renewable and Sustainable Energy Reviews, 54, pp. 1323-1333, 2016. https://doi.org/10.1016/j.rser.2015.10.092

[2] Sengul, O. "Mechanical behavior of concretes containing waste steel fibers recovered from scrap tires", Construction and Building Materials, 122, pp. 649-658, 2016.

https://doi.org/10.1016/j.conbuildmat.2016.06.113
- High axial strains (317\% of plain concrete) were reported for CFRP confined rubberized concrete. These results clearly show that there is a great potential of using CFRP-confined rubberized concrete in practical structural engineering applications.

- The current design codes developed for conventional concrete confinement are not adopted for rubberized concrete confinement. The existing strength models i.e., Canadian Standard Association (CSA S806-02), American Concrete Institute (ACI 440.2R.08), Intelligent Sensing for Innovative Structures Canada (ISIS M04.01), Fédération Internationale du Béton (fib-14), and Concrete Society (CS TR.55) were highly conservative for strength prediction of CFRP confined RuC. However, American Concrete Institute code (ACI-318) provided better prediction of test results for CFRP-confined concrete with fine rubber content.

- The developed strength model predicts the experimental test results of CFRP-confined rubberized concrete with high accuracy. However, the strength equations should only be used with in the defined parameters and extreme care is needed to predict the confined strength with other FRP types.

\section{Recommendations}

The future research should also be directed towards other types of confinement methods for rubberized concrete and to increase the database of experimental studies that will contribute to take full potential of rubberized concrete confinement.

\section{Acknowledgment}

The project presented in this article is supported by Sichuan University.

[3] Huang, S.-S., Angelakopoulos, H., Pilakoutas, K., Burgess, I. "Reused tyre polymer fibre for fire-spalling mitigation", presented at Applications of Structural Fire Engineering International Conference in Dubrovnik, Dubrovnik, Croatia, Oct. 15-16, 2015. https://doi.org/10.14311/asfe.2015.056

[4] Goulias, D. G., Ali, A.-H. "Evaluation of rubber-filled concrete and correlation between destructive and nondestructive testing results", Cement, Concrete and Aggregates, 20(1), pp. 140-144, 1998. https://doi.org/10.1520/CCA10447J 
[5] Son, K. S., Hajirasouliha, I., Pilakoutas, K. "Strength and deformability of waste tyre rubber-filled reinforced concrete columns", Construction and Building Materials, 25(1), pp. 218-226, 2011. https://doi.org/10.1016/j.conbuildmat.2010.06.035

[6] Youssf, O., ElGawady, M., Mills, J. E., Ma, X. "Experimental and finite element investigation of rubberized concrete confined by FRP", presented at 26th Biennial Conference of Concrete Institute of Australia, Gold Coast, QLD, Australia, Oct. 16-18, 2013. https://doi.org/10.13140/2.1.4333.9843

[7] Raffoul, S., Garcia, R., Escolano-Margarit, D., Guadagnini, M., Hajirasouliha, I., Pilakoutas, K. "Behaviour of unconfined and FRPconfined rubberised concrete in axial compression", Construction and Building Materials, 147, pp. 388-397, 2017. https://doi.org/10.1016/j.conbuildmat.2017.04.175

[8] Xue, J., Shinozuka, M. "Rubberized concrete: A green structural material with enhanced energy-dissipation capability", Construction and Building Materials, 42, pp. 196-204, 2013. https://doi.org/10.1016/j.conbuildmat.2013.01.005

[9] Guo, S., Dai, Q., Si, R., Sun, X., Lu, C. "Evaluation of properties and performance of rubber-modified concrete for recycling of waste scrap tire", Journal of Cleaner Production, 148, pp. 681-689, 2017. https://doi.org/10.1016/j.jclepro.2017.02.046

[10] Liu, H., Wang, X., Jiao, Y., Sha, T. "Experimental investigation of the mechanical and durability properties of crumb rubber concrete", Materials, 9(3), Article number: 172, 2016. https://doi.org/10.3390/ma9030172

[11] Youssf, O., Mills, J. E., Hassanli, R. "Assessment of the mechanical performance of crumb rubber concrete", Construction and Building Materials, 125, pp. 175-183, 2016.

https://doi.org/10.1016/j.conbuildmat.2016.08.040

[12] Ozbakkaloglu, T., Idris, Y. "Seismic Behavior of FRP-HighStrength Concrete-Steel Double-Skin Tubular Columns", Journal of Structural Engineering, 140(6), Article number: 04014019, 2014. https://doi.org/10.1061/(ASCE)ST.1943-541X.0000981

[13] De Luca, A., Nardone, F., Matta, F., Nanni, A., Lignola, G. P., Prota, A. "Structural Evaluation of Full-Scale FRP-Confined Reinforced Concrete Columns", Journal of Composites for Construction, 15(1), pp. 112-123, 2010.

https://doi.org/10.1061/(ASCE)CC.1943-5614.0000152

[14] Bournas, D. A., Lontou, P. V., Papanicolaou, C. G., Triantafillou, T. C. "Textile-Reinforced Mortar versus Fiber-Reinforced Polymer Confinement in Reinforced Concrete Columns", ACI Structural Journal, 104(6), pp. 740-748, 2007.

https://doi.org/10.14359/18956

[15] Li, G., Pang, S-S., Ibekwe, S. I. "FRP tube encased rubberized concrete cylinders", Materials and Structures, 44, pp. 233-243, 2011. https://doi.org/10.1617/s11527-010-9622-8

[16] Youssf, O., Hassanli, R., Mills, J. E. "Mechanical performance of FRP-confined and unconfined crumb rubber concrete containing high rubber content", Journal of Building Engineering, 11, pp. 115126, 2017.

https://doi.org/10.1016/j.jobe.2017.04.011
[17] Benzaid, R., Mesbah, H. A. "Circular and Square Concrete Columns Externally Confined by CFRP Composite: Experimental Investigation and Effective Strength Models", In: Masuelli, M. (ed.) Fiber Reinforced Polymers - The Technology Applied for Concrete Repair, InTech Open, Rijeka, Croatia, 2013. https://doi.org/10.5772/51589

[18] Lam, L., Teng, J. G. "Design-oriented stress-strain model for FRPconfined concrete", Construction and Building Materials, 17(6-7), pp. 471-489, 2003. https://doi.org/10.1016/S0950-0618(03)00045-X

[19] Rocca, S., Galati, N., Nanni, A. "Review of Design Guidelines for FRP Confinement of Reinforced Concrete Columns of Noncircular Cross Sections", Journal of Composites for Construction, 12(1), pp. 80-92, 2008.

https://doi.org/10.1061/(ASCE)1090-0268(2008)12:1(80)

[20] ACI Committee 440 "Guide for the design and construction of externally bonded FRP systems for strengthening concrete structures", American Concrete Institute, Farmington Hills, MI, USA, Rep. ACI PRC-440.2-17, 2008.

[21] CSA "CAN/CSA-S806-02 Design and Construction of Building Components with Fibre Reinforced Polymer", Canadian Standards Association, Mississauga, ON, Canada, 2002.

[22] Neale, K. W. "Strengthening Reinforced Concrete Structures with Externally-bonded Fibre Reinforced Polymers", ISIS Canada Research Network, Winnipeg, MB, Canada, 2001.

[23] Yazici, V., Hadi, M. N. "Normalized Confinement Stiffness Approach for Modeling FRP-Confined Concrete", Journal of Composites for Construction, 16(5), pp. 520-528, 2012. https://doi.org/10.1061/(ASCE)CC.1943-5614.0000283

[24] Bisby, L. A., Dent, A. J. S., Green, M. F. "Comparison of Confinement Models for FRP Wrapped Concrete", ACI Structural Journal, 102(1), pp. 62-72, 2005.

[25] Tufail, R. F., Yaqub, M., Khan, Q. Z., Mehboob, S. S., Sohail, M. R. "Experimental versus design guideline predictions for confined strength and axial load carrying capacity of circular concrete cylinders wrapped with CFRP", Life Science Journal, 10(12s), pp. 684-695, 2013

[26] Moran, D. A., Pantelides, C. P. "Stress-Strain Model for FiberReinforced Polymer-Confined Concrete", Journal of Composites for Construction, 6(4), pp. 233-240, 2002. https://doi.org/10.1061/(ASCE)1090-0268(2002)6:4(233)

[27] Mohamed, H. M., Masmoudi, R. "Axial Load Capacity of ConcreteFilled FRP Tube Columns: Experimental versus Theoretical Predictions", Journal of Composites for Construction, 14(2), pp. 231-243, 2010. https://doi.org/10.1061/(ASCE)CC.1943-5614.0000066

[28] Rochette, P., Labossiere, P. "Axial Testing of Rectangular Column Models Confined with Composites", Journal of Composites for Construction, 4(3), pp. 129-136, 2000. https://doi.org/10.1061/(ASCE)1090-0268(2000)4:3(129)

[29] fib "Externally bonded FRP reinforcement for RC structures", International Federation for Structural Concrete, Lausanne, Switzerland, Bulletin 14, 2001 https://doi.org/10.35789/fib.BULL.0014 
[30] ASTM "ASTM C39 / C39M - 12 Standard Test Method for Compressive Strength of Cylindrical Concrete Specimens", ASTM International, West Conshohocken, PA, USA, 2012. https://doi.org/10.1520/C0039_C0039M-12

[31] Richart, F. E., Brandtzæg, A., Brown, R. L. "Failure of plain and spirally reinforced concrete in compression", University of Illinois Bulletin 26(31), Bulletin 190, 1929. [online] Available at: http://hdl. handle.net/2142/4073

[32] Lam, L., Teng, J. G. "Strength Models for Fiber-Reinforced PlasticConfined Concrete", Journal of Structural Engineering, 128(5), pp. 612-623, 2002.

https://doi.org/10.1061/(ASCE)0733-9445(2002)128:5(612)

[33] Micelli, F., Modarelli, R. "Experimental and analytical study on properties affecting the behaviour of FRP-confined concrete", Composites Part B: Engineering, 45(1), pp. 1420-1431, 2013. https://doi.org/10.1016/j.compositesb.2012.09.055

[34] Valdmanis, V., De Lorenzis, L., Rousakisand T., Tepfers R. "Behaviour and capacity of CFRP-confined concrete cylinders subjected to monotonic and cyclic axial compressive load", Structural Concrete, 8(4), pp. 187, 2007.

https://doi.org/10.1680/stco.2007.8.4.187
[35] Fardis, M. N., Khalili, H. "Concrete Encased in Fiberglass-Reinforced Plastic", ACI Journal Proceedings, 78(6), pp. 440-446, 1981. https://doi.org/10.14359/10527

[36] Ozbakkaloglu, T., Gholampour, A., Lim, J. C. "Damage-Plasticity Model for FRP-Confined Normal-Strength and High-Strength Concrete", Journal of Composites for Construction, 20(6), Article number: 04016053, 2016. https://doi.org/10.1061/(ASCE)CC.1943-5614.0000712

[37] Fardis, M. N., Khalili, H. H. "FRP-encased concrete as a structural material", Magazine of Concrete Research, 34(121), pp. 191-202, 1982.

https://doi.org/10.1680/macr.1982.34.121.191

[38] Arya, C., Clarke, J. L., Kay, E. A., O'Regan, P. D. "TR 55: Design guidance for stengthening concrete structures using fibre composite materials: a review", Engineering Structures, 24(7), pp. 889-900, 2002.

https://doi.org/10.1016/S0141-0296(02)00027-5

[39] Pham, T. M., Hadi, M. N. S. "Confinement model for FRP confined normal-and high-strength concrete circular columns" Construction and Building Materials, 69, pp. 83-90, 2014.

https://doi.org/10.1016/j.conbuildmat.2014.06.036 